\title{
Toxic Effects of Anatase Titanium Dioxide Nanoparticles on Spermatogenesis and Testicles in Male Mice
}

\author{
Guanling Song, Lin Lin, Longlong Liu, Kui Wang, Yusong Ding, Qiang Niu, \\ Lati Mu, Haixia Wang, Hui Shen, Shuxia Guo* \\ Department of Public Health and Key Laboratory of Xinjiang Endemic and Ethnic Diseases (Ministry of Education), \\ School of Medicine, Shihezi University, Shihezi 832002, Xinjiang, China
}

Received: 15 March 2017

Accepted: 27 April 2017

\begin{abstract}
Anatase $\mathrm{TiO}_{2}$ nanoparticles (NPs) are widely used in food products, capsules, toothpaste, and so on, so the kinds of NPs directly get in touch with human bodies. The potential effect of this kind of material on reproduction must be considered with the increase in infertility. Sixty ICR male mice were intragastrically treated with dosages of $0,10,50$, and $100 \mathrm{mg} \mathrm{kg}^{-1}$ body weight $(\mathrm{BW})$ anatase $\mathrm{TiO}_{2} \mathrm{NPs}$ to investigate the male reproductive toxicity of the NPs. Sperm quality, morphological changes in mice testes, and oxidative damage indexes were investigated in this study. Results showed that anatase $\mathrm{TiO}_{2} \mathrm{NPs}$ could lead to sperm malformation and increased rate of sperm cell micronucleus. These NPs also reduced the germ cell number and led to spherospermia, interstitial glands vacuole, malalignment, and vacuolization of spermatogenic cells in mice testes. Testicular cells accumulated reactive oxygen species when the mice were intragastrically administrated with $\mathrm{TiO}_{2}$ NPs. Superoxide dismutase activity decreased, and the malondialdehyde content increased in the $\mathrm{TiO}_{2} \mathrm{NP}$-treated groups. Anatase $\mathrm{TiO}_{2} \mathrm{NPs}$ exerted potential toxic effects on male reproduction, so the widespread application of this kind of NP in food products needs to be regulated.
\end{abstract}

Keywords: $\mathrm{TiO}_{2} \mathrm{NPs}$, male reproductive toxicity, sperm quality, morphological change, oxidative damage

\section{Introduction}

Nanoparticles (NPs) are particles with at least one of their three dimensions in the range of 1-100 $\mathrm{nm}$ [1-2]. NPs generally possess dramatically different physicochemical properties compared to fine particles (FPs) [3] of the same composition. Titanium dioxide NPs (nano- $\mathrm{TiO}_{2}$ ), a kind

*e-mail: gsxshzu@sina.com of noncombustible and odorless powder, mainly exist in three crystalline forms: rutile, anatase, and brookite [4]. Nowadays, nano- $\mathrm{TiO}_{2}$ is widely produced and used in paints, cosmetics, plastics, and food [5-6], and about 1.45 million metric tons of $\mathrm{TiO}_{2} \mathrm{NPs}$ were produced in the United States in 2007 alone [7]. Among the three crystalline forms, anatase nano- $\mathrm{TiO}_{2}$ is the most widely used in products by direct contact with human blood such as foods, capsules, toothpaste, and so on [8-10]. Human exposure to anatase $\mathrm{TiO}_{2}$ NPs can occur via various routes. For consumers, the oral and dermal routes are considered 
most relevant based on potential external exposure to consumer products. Oral exposure may occur, because regularly consumed food products contain anatase $\mathrm{TiO}_{2}$ NPs [11].

The potential toxic effect of anatase nano- $\mathrm{TiO}_{2}$ on health must be given attention because of its extensive use. $\mathrm{TiO}_{2} \mathrm{NPs}_{\text {can }}$ be absorbed into the circulation of the human body mainly through inhalation, indigestion, and skin penetration. These NPs may then be redistributed into other tissues (such as the liver, heart, and lung), which can induce impairments on organs after unintentional exposure. Although $\mathrm{TiO}_{2}$ NPs have been demonstrated to accumulate in organs and result in toxicity, data regarding male reproductive toxicity caused by $\mathrm{TiO}_{2} \mathrm{NPs}$ are currently limited [12]. The limited data showed that $\mathrm{TiO}_{2}$ NPs exhibit male reproductive toxicity. $\mathrm{TiO}_{2} \mathrm{NPs}$ can be absorbed by Leydig cells, thereby affecting viability, proliferation, and gene expression. $\mathrm{TiO}_{2}$ NPs can cross the blood-testis barrier to reach the testis and accumulate, resulting in testicular lesions, alterations in serum sex hormone levels, and cell apoptosis [13-15]. The effects of $\mathrm{TiO}_{2}$ NPs on other indexes and the toxic mechanism on males also needs to be further studied.

The effects of anatase $\mathrm{TiO}_{2}$ NPs on testis coefficient, epididymis coefficient, sperm density, rate of teratosperm, sperm activity rate, and micronucleus $(\mathrm{MN})$ rate of testis cells in ICR mice were investigated to further study its male reproductive toxicity in vivo. Superoxide dismutase (SOD) activity and the malondialdehyde (MDA) content of testicular tissues, as well as testicular histopathology changes, were also studied when the mice were exposed to different concentrations of $\mathrm{TiO}_{2}$ NPs through intragastric treatment for 30 days. The research can offer replenishment on male toxic effects induced by anatase $\mathrm{TiO}_{2}$ NPs in subacute toxic condition.

\section{Materials and Methods}

\section{Animal Husbandry}

A total of 60 six-week-old healthy male ICR mice were purchased from the experimental animal center of Xinjiang Medical University (production permit No.: SCXK (xin) 2011-0003). The mice were raised in the animal center of the medical school of Shihezi University for seven days before the experiment. The room was airconditioned at $22 \pm 2^{\circ} \mathrm{C}$, with $50-70 \%$ relative humidity and $12 \mathrm{~h}$ of light. Food and water were provided ad libitum. The ammonia concentration and undesired sound were maintained at $\leq 5 \mathrm{mg} \mathrm{ml}^{-1}$ and $60 \mathrm{db}$, respectively, in the animal center.

\section{Chemicals and Treatments}

Anatase $\mathrm{TiO}_{2}$ NPs were purchased from Shanghai Jingchun Reagent. The $\mathrm{TiO}_{2}$ NPs had a purity greater than $99.8 \%$, particle diameter of $5-10 \mathrm{~nm}$, and surface area of $120 \mathrm{~m}^{2} \mathrm{~g}^{-1}$. The morphology of the $\mathrm{TiO}_{2} \mathrm{NPs}$ was examined using transmission electron microscopy (TEM; JEOL 100CX). The TEM image of individual $\mathrm{TiO}_{2}$ NPs showed that the particles were nearly rhabditiform in shape. Particle diameter was approximately $10 \mathrm{~nm}$ [16].

Nano- $\mathrm{TiO}_{2}$ was dispersed in PBS ( $\mathrm{pH}$ 7.4) with $0.5 \%$ Tween 80 and prepared via ultrasonication for 30 min immediately before use. All 60 male mice were randomly divided into four groups $(\mathrm{n}=15)$. Nano- $\mathrm{TiO}_{2}$ solution was orally and intragastrically administered to three groups at dosages of 10,50 , or $100 \mathrm{mg} / \mathrm{kg}$ body weight (BW) per day for 28 days. Mice of the control group were treated with PBS ( $\mathrm{pH} 7.4$ ) with $0.5 \%$ Tween 80 only. The mice fasted for $4 \mathrm{~h}$ before and after intragastric administration.

\section{Observation of Indexes}

All of the male mice were observed daily for mortality, morbidity, general appearance, and behavior throughout the treatment period. The BWs of the mice were measured every three days. Testes and accessory sex organs were weighed to the nearest milligram on a Shimadzu electronic balance (model BL-220H, Tokyo, Japan). The index weight of the organs was calculated by the following formula:

$$
\text { sex organ index }=\text { organ weight } \div \mathrm{BW} \times 100 \%
$$

\section{Sperm Quality}

The cauda epididymal sperm suspension was prepared in normal saline at $37^{\circ} \mathrm{C}$. Sperm viability (live/ dead ratio) and density were calculated by the method of Nahas et al. [17], and expressed as percentage viability and sperm $\times 10^{6} \mathrm{ml}^{-1}$, respectively. The percentage of abnormal sperm was scored in 10-20 separate fields using 1\% trypan blue following the method of Okamura [18]. Sperm motility analysis was carried out at room temperature using one epididymis from each rat. The percentage of sperm motility was calculated using the number of live sperm cells divided by the total number of sperm cells (motile and non-motile) from two samples per epididymis of each rat. All sperm cells that were not moving at all were considered non-motile, whereas the rest, which displayed some movement, were considered motile [19].

\section{MN Rates of Spermatogenic Cells}

Tissue sections without envelopes were cut into pieces and mixed with $10 \mathrm{ml} \mathrm{TM}$ buffer, and $15 \mathrm{mg}$ pancreatic enzyme was added into the mixture, which was mixed at a low rate by a magnetic stirrer for $15 \mathrm{~min}$, filtered with filter paper, and centrifuged at 1,000 g for $15 \mathrm{~min}$. TM buffer was added to make a cell suspension after the supernatant was discarded. A smear of the cell suspension was dyed with Giemsa dye liquor for $20 \mathrm{~min}$ after natural drying 
and formalin fixation. The MN rate was represented in permillage.

\section{Histopathological Examination of Testis Tissues}

Tissue sections were obtained from testes of the mice in each group immediately after sacrifice. The tissues were washed with normal saline solution to remove blood, fixed in $10 \%$ neutral formalin for at least $24 \mathrm{~h}$, dehydrated in different grades of alcohol, and processed for paraffin embedding. Sections of $5 \mu \mathrm{m}$ thickness were cut using a rotary microtome. The sections were processed and passed through a graded alcohol series, stained with hematoxylin and eosin, cleared in xylene, and examined with an Olympus microscope (CX21FS1, Japan) following the procedure reported by Bancroft et al [20].

\section{Enzyme Extraction and Total Protein Examination}

Tissue homogenates were prepared using testis tissues in cold normal saline. The homogenate was centrifuged at $15,000 \mathrm{~g}\left(4^{\circ} \mathrm{C}\right)$ for $15 \mathrm{~min}$. The supernatant was used as enzyme extract. The protein concentration in the homogenate was measured with a Bradford protein assay kit (Nanjing Jiancheng Bioengineering Institute, Nanjing, China).

\section{Analysis of SOD Activity and MDA Content}

SOD activity and MDA content were measured using detection kits from the Nanjing Jiancheng Bioengineering Institute. The assays were carried out according to the specifications of the detection kits.

\section{Statistical Analysis}

Results are expressed as the mean \pm standard deviation. Data were evaluated by Student's $t$-test and compared with their corresponding control $(0 \mathrm{mg} / \mathrm{kg} \mathrm{BW} \mathrm{TiO}, \mathrm{NPs})$ using the statistical package Prism 5.0. Statistical significance was set at $\mathrm{p}<0.05$.

\section{Results and Discussion}

\section{Characterization of $\mathrm{TiO}_{2} \mathrm{NPs}$ Particles in PBS Solution}

The particle diameter of the NPs in the PBS solution decreased with the increase of NP concentration in the solution (Fig. 1). The zeta potentials of $\mathrm{TiO}_{2} \mathrm{NPs}$ in the solution are shown in Fig. 2. Zeta potentials of $\mathrm{TiO}_{2} \mathrm{NPs}$ were all negative, and the zeta potentials of these $\mathrm{TiO}_{2} \mathrm{NPs}$ increased with the increase of $\mathrm{TiO}_{2} \mathrm{NPs}$ concentrations.
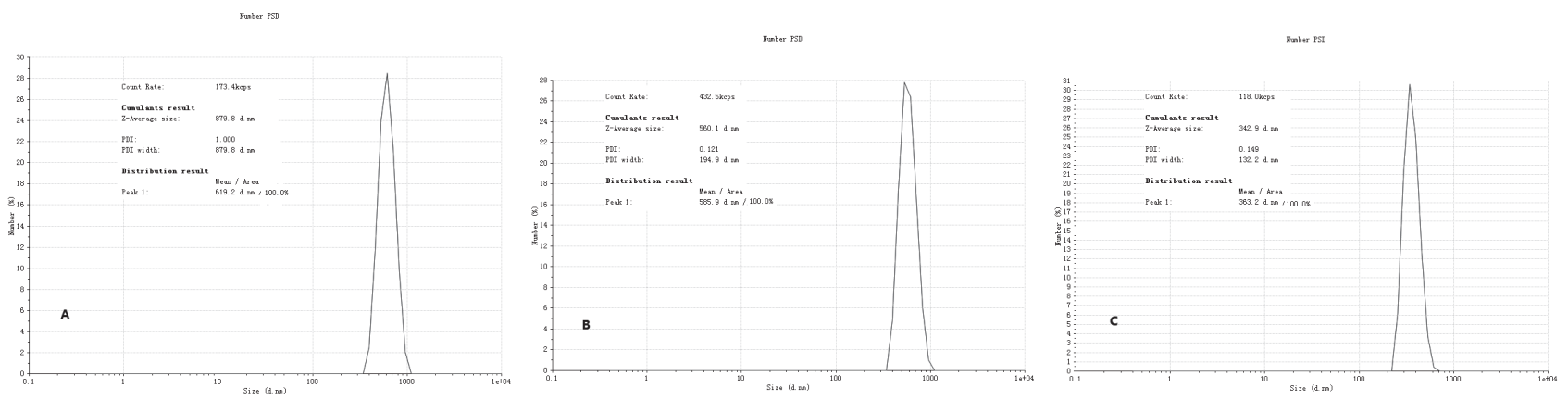

Fig. 1. Particle diameter of the NPs in PBS solution: A) particle diameter of the NPs in the solution of administered dosage of $10 \mathrm{mg} \mathrm{kg}$ $\left.{ }^{1} \mathrm{BW}, \mathrm{B}\right)$ particle diameter of the NPs in the solution of administered dosage of $50 \mathrm{mg} \mathrm{kg}^{-1} \mathrm{BW}$, and C) particle diameter of the NPs in the solution of administered dosage of $100 \mathrm{mg} \mathrm{kg}^{-1} \mathrm{BW}$.
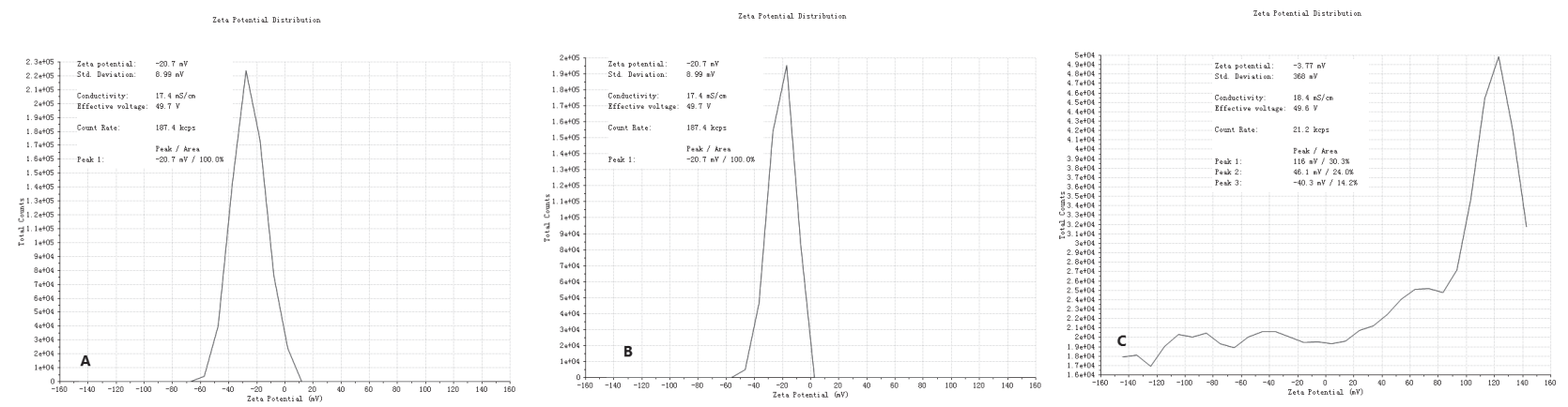

Fig. 2. Zeta potentials of the NPs in PBS solution: A) Zeta potentials of the NPs in the solution of administered dosage of $10 \mathrm{mg} \mathrm{kg}^{-1} \mathrm{BW}$, B) Zeta potentials of the NPs in the solution of administered dosage of $50 \mathrm{mg} \mathrm{kg}^{-1} \mathrm{BW}$, and C) Zeta potentials of the NPs in the solution of administered dosage of $100 \mathrm{mg} \mathrm{kg}^{-1} \mathrm{BW}$. 
Particle diameter is an important factor for NPs in the aqueous phase. Smaller NPs have larger surface-tovolume ratios, which leads to the higher capacity of NPs to be absorbed on the surface of organisms. The particle diameter of the NPs in the PBS solution decreased with the increase of NP concentration in the solution, meaning that the capacity of $\mathrm{TiO}_{2} \mathrm{NP}$ particles to be absorbed increased with the exposed dosage increase to some extent.

The value of the zeta potential can be related to the stability of colloidal dispersion. The zeta potential indicates the degree of repulsion between adjacent, similarly charged particles in the dispersion. If the zeta potential absolute value of the particles is higher in a solution, the solution or dispersion has a high capacity to resist aggregation. When the zeta potential absolute value of the particles in a solution is low, attraction exceeds repulsion and the dispersion will break and flocculate. The general dividing line between stable and unstable suspensions is generally taken at either +30 or $-30 \mathrm{mV}$. Particles with zeta potentials more positive than $+30 \mathrm{mV}$ or more negative than $-30 \mathrm{~m}$ Vare normally considered stable [21]. The results of the present study indicate that the colloidal dispersion of these culture media decreased with the particle concentration increase, and all of the solutions were stable in general.

\section{Effect of $\mathrm{TiO}_{2}$ NPs on BW and Organ Indexes}

The mortality, morbidity, general appearance, and behavior of mice in all treatment shows no differences. The effect of $\mathrm{TiO}_{2}$ NPs on the BW is shown in Fig. 3 . No significant differences were found between the BWs of the $\mathrm{TiO}_{2}$ NP-treated groups and control group ( $\left.>0.05\right)$. After more than two weeks of post-exposure to $\mathrm{TiO}_{2} \mathrm{NPs}$ (129.4 $\mathrm{nm}$ in $\mathrm{H}_{2} \mathrm{O} ; 175,550,1,750$, or $5,000 \mathrm{mg} \mathrm{kg}^{-1} \mathrm{BW}$; $80 / 20$ anatase/rutile; $48 \mathrm{~h}$ intervals for 14 days), $\mathrm{TiO}_{2}$

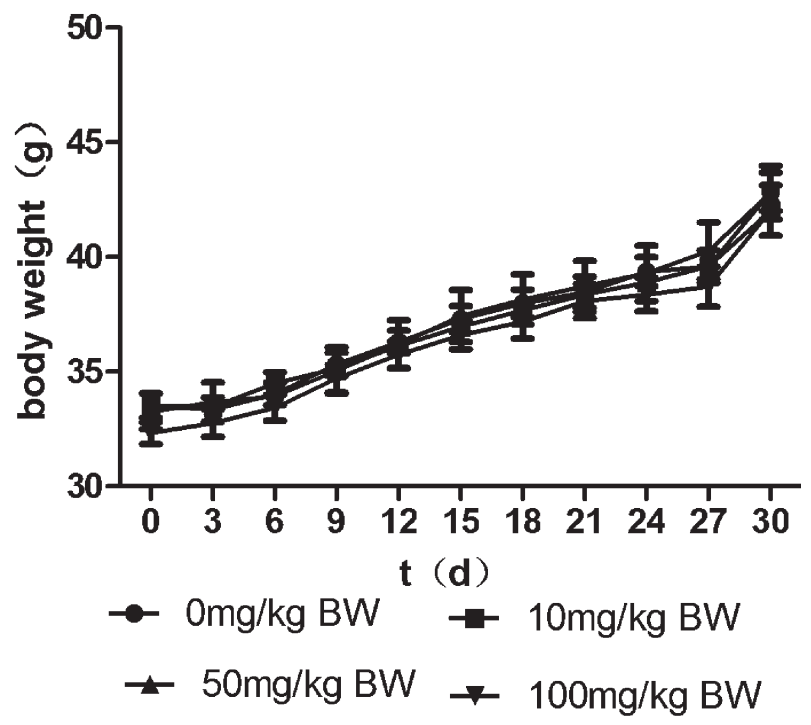

Fig. 3. BW of male mice in the $\mathrm{TiO}_{2}$ NP-treated groups and control group.
Table 1. Testicle and epididymis indexes of the $\mathrm{TiO}_{2}$ NP-treated groups and control group.

\begin{tabular}{|c|c|c|}
\hline Groups & $\begin{array}{c}\text { Testicle index } \\
\left(\mathrm{mg} \mathrm{g}^{-1}\right)\end{array}$ & $\begin{array}{c}\text { Epididymis index } \\
\left(\mathrm{mg} \mathrm{g}^{-1}\right)\end{array}$ \\
\hline $0 \mathrm{mg} \mathrm{kg}^{-1} \mathrm{BW}$ & $7.19 \pm 1.03$ & $0.42 \pm 0.06$ \\
\hline $10 \mathrm{mg} \mathrm{kg}^{-1} \mathrm{BW}$ & $7.48 \pm 0.75$ & $0.44 \pm 0.24$ \\
\hline $50 \mathrm{mg} \mathrm{kg}^{-1} \mathrm{BW}$ & $6.09 \pm 1.3$ & $0.60 \pm 0.09$ \\
\hline $100 \mathrm{mg} \mathrm{kg}^{-1} \mathrm{BW}$ & $7.44 \pm 1.71$ & $0.41 \pm 0.24$ \\
\hline
\end{tabular}

Values are mean $\pm \mathrm{SEM}, * \mathrm{p}<0.05$ vs. $\mathrm{TiO}_{2} \mathrm{NP}$-treated groups and control group

Abbreviations: $\mathrm{BW}=$ body weight

NPs did not exhibit high or any obvious acute toxicity from BW changes [10]. Our studies also indicated that $\mathrm{TiO}_{2}$ NPs with diameters measuring 5-10 nm showed no obvious effect on the BWs of male mice during prolonged exposure and at the maximum dose of $100 \mathrm{mg} / \mathrm{kg} \mathrm{BW}$.

When particles become progressively smaller, their surface areas, in turn, become progressively larger. Researchers have also expressed concerns about the harmful effects of $\mathrm{TiO}_{2}$ NPs on human health associated with the decrease in size [22-23]. The diameter of $\mathrm{TiO}_{2}$ NPs in our research was only 5-10 nm, and they showed no significant difference in mice BW and male organs of generation weight. Such a result may explain the prevalent use of $\mathrm{TiO}_{2}$ NPs in food products.

The effects of $\mathrm{TiO}_{2}$ NPs on the testicle and epididymis indexes of male mice from the $\mathrm{TiO}_{2} \mathrm{NP}$-treated groups and control group are shown in Table 1. No significant difference was observed between the testicle and epididymis indexes of the $\mathrm{TiO}_{2}$ NP-treated groups and control group $(\mathrm{p}>0.05)$. The results also indicated that $\mathrm{TiO}_{2}$ NPs did not affect the weight of the testicles and epididymis of male mice.

\section{Effect of $\mathrm{TiO}_{2}$ NPs on Sperm Quality and MN Rates of Spermatogenic Cells}

The effects of $\mathrm{TiO}_{2}$ NPs on sperm quality and MN rates of spermatogenic cells are shown in Fig. 4. The sperm densities of all the mice in this research were not significantly different; however, sperm malformation and sperm cell MN rate increased with increasing dosages of $\mathrm{TiO}_{2}$ NPs. Sperm malformation and sperm cell MN rate of the treatment mice groups showed significant differences $(\mathrm{p}<0.01)$ when the $\mathrm{TiO}_{2} \mathrm{NPs}$ dosages attained $50 \mathrm{mg} \mathrm{kg}^{-1}$ BW.

In a previous report, mice received $300 \mathrm{mg} \mathrm{kg}^{-1} \mathrm{TiO}_{2}$ NPs for 35 days and the epididymal sperm parameters, including sperm number, motility, and percentage of abnormality, significantly changed $(p<0.01)$ [24]. The results in Fig. 2 also show that $\mathrm{TiO}_{2}$ NPs exerted a toxic effect on male reproductive cells. Therefore, male reproductive cells may be highly sensitive to $\mathrm{TiO}_{2}$ NPs compared with body cells. 
a)

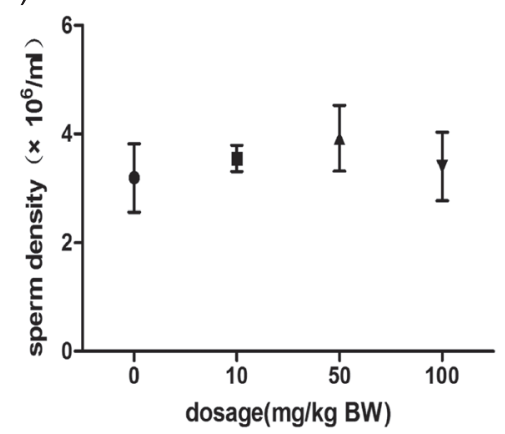

b)

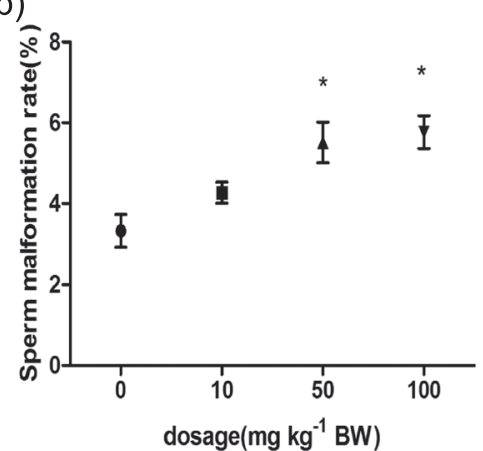

c)

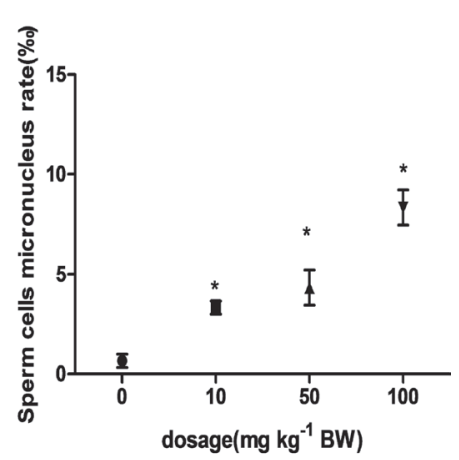

Fig. 4. Sperm quality and MN rates of spermatogenic cells.

\section{Morphological Changes in the Testis Among Different Treatment Groups}

The effects of $\mathrm{TiO}_{2}$ NPs on morphological changes in mice testes are shown in Fig. 5. $\mathrm{TiO}_{2}$ NPs caused a reduction in germ cell number and led to spherospermia, interstitial glands, malalignment, and vacuolization in spermatogenic cells. The morphology of testis tissues in the low dosage $\left(10 \mathrm{mg} \mathrm{kg}^{-1} \mathrm{BW}\right)$ group showed no remarkable changes compared with that of the control, except that more spherospermia were observed in the middle of tissues. Spermatogenic cells in testis tissues became disorderly and vacuolized from the middle dosage (50 $\mathrm{m} \mathrm{kg}^{-1} \mathrm{BW}$ ) group.
SOD Activity and MDA Content of Mice Testes Among Different Treatment Groups

The mitochondria of animal cells are important intracellular generators of reactive oxygen species (ROS). When animal cells encounter oxidative stress, the mitochondria are particularly prone to generating ROS, which can remarkably disrupt normal metabolism through oxidative damage of lipids, nucleic acids, and proteins. The deleterious effects of ROS and lipid peroxidation products are counteracted by an antioxidant defensive system [25].

SOD activity decreased when the mice were exposed to $\mathrm{TiO}_{2}$ NPs. SOD activity of mice testes significantly

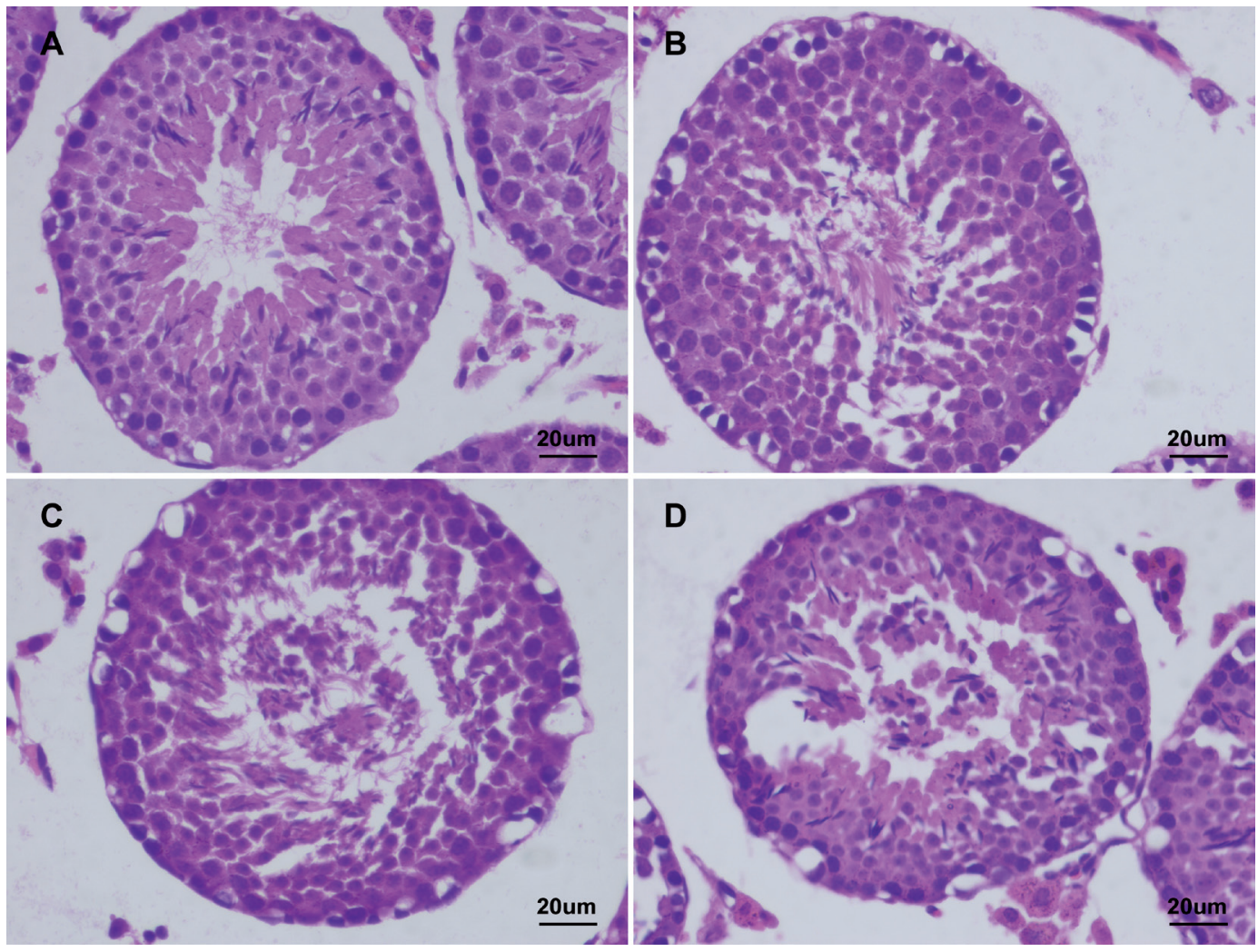

Fig. 5. Testis morphology of different mice groups: a) testis morphology of mice in control, b) testis morphology of mice in $10 \mathrm{mg} \mathrm{kg}^{-1}$ $\mathrm{BW} \mathrm{TiO}{ }_{2} \mathrm{NPs}$, c) testis morphology of mice in $50 \mathrm{mg} \mathrm{kg}^{-1} \mathrm{BW} \mathrm{TiO}_{2} \mathrm{NPs}$, and D) testis morphology of mice in $100 \mathrm{mg} \mathrm{kg}^{-1} \mathrm{BW} \mathrm{TiO}_{2} \mathrm{NPs}_{\text {. }}$ 


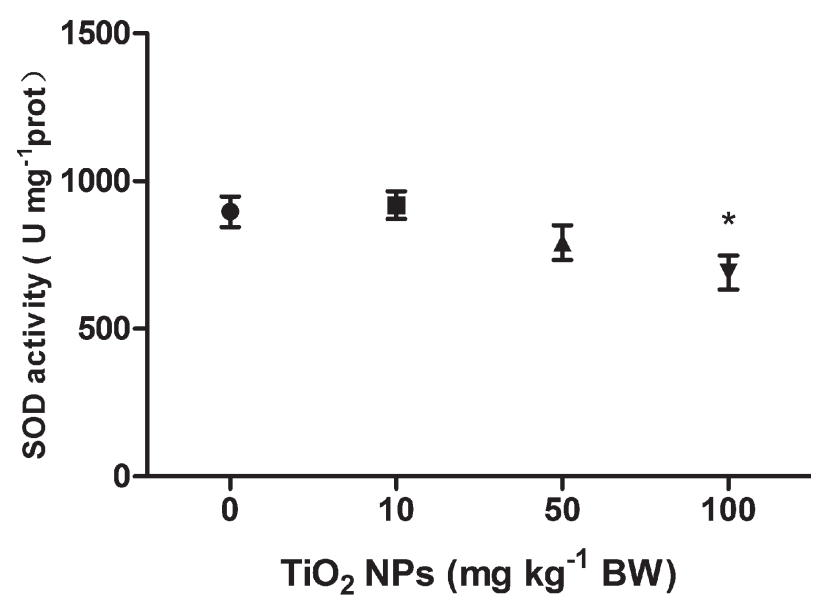

Fig. 6. SOD activity changes in mice testes among different treatment groups.

decreased in the high-dosage (100 $\mathrm{mg} \mathrm{kg}^{-1} \mathrm{BW}$ ) group compared with that in the control group $(\mathrm{p}<0.05)$ (Fig. 6).

The SOD enzyme is a major scavenger of $\mathrm{O}^{2-}$, and its enzymatic action results in the formation of $\mathrm{H}_{2} \mathrm{O}_{2}$ and $\mathrm{O}_{2}$. SOD performs a pivotal function in combating oxidative stress in plants, and a marked increase in SOD activity has been demonstrated to occur upon exposure to oxidative stress [26]. SOD activity of mice testes decreased in the $\mathrm{TiO}_{2}$ NP-treated groups, which suggested that the decomposition of $\mathrm{O}^{2-}$ to $\mathrm{H}_{2} \mathrm{O}_{2}$ and $\mathrm{O}_{2}$ decreased in mice testes.

The MDA contents of mice testes in the different treatment groups are shown in Fig. 7, which demonstrated that the MDA contents increased when the mice were exposed to $\mathrm{TiO}_{2}$ NPs. The MDA content of mice testes from the $50 \mathrm{mg} \mathrm{kg}^{-1} \mathrm{BW} \mathrm{TiO}_{2} \mathrm{NP}$ treatment group significantly increased compared with that of the control $(\mathrm{p}<0.01)$.

MDA is the decomposition product of polyunsaturated fatty acids of biomembranes, and its increase is a result of significant accumulation under high antioxidant stress. The MDA content serves as an indicator of the extent

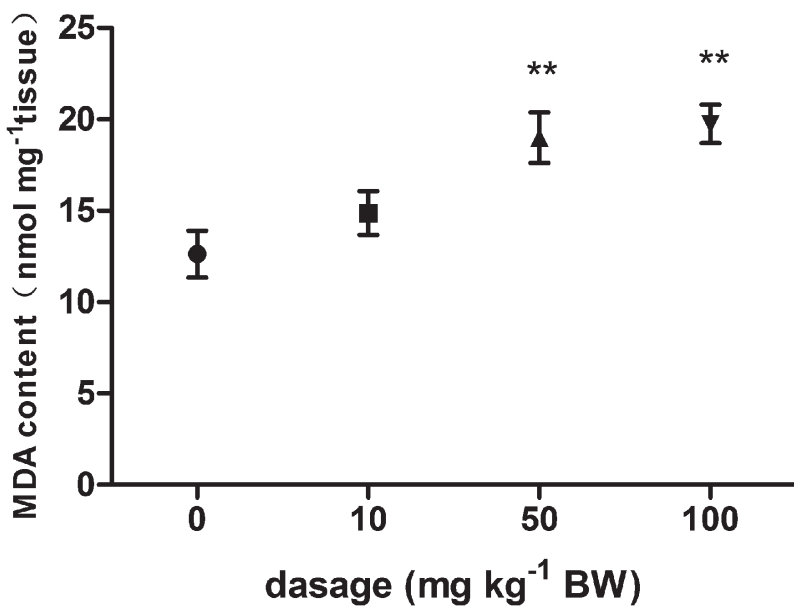

Fig. 7. MDA content of mice testes in different treatment groups. of lipid peroxidation and is an indirect reflection of the extent of cell damage [27]. The significant increase in the MDA content in mice testes indicated the serious damage incurred by testis cells when the mice were exposed to $\mathrm{TiO}_{2}$ NPs.

\section{Conclusions}

$\mathrm{TiO}_{2}$ NPs exerted a toxic effect on male reproduction. Sperm malformation and the sperm cell $\mathrm{MN}$ rate increased when male mice were intragastrically treated with $\mathrm{TiO}_{2}$ NPs. However, the testicle and epididymis indexes were not significantly different compared with those of the control group. $\mathrm{TiO}_{2}$ NPs also caused a reduction in the germ cell number and led to spherospermia, interstitial glands, malalignment, and vacuolization of spermatogenic cells in testis tissues. Testicular cells accumulated ROS when the mice were intragastrically treated with $\mathrm{TiO}_{2}$ NPs. SOD activity significantly decreased in testis tissues when the dosage of $\mathrm{TiO}_{2} \mathrm{NPs}$ reached $100 \mathrm{mg} \mathrm{kg}^{-1} \mathrm{BW}$, and cells from the group treated with $50 \mathrm{mg} \mathrm{kg}^{-1} \mathrm{BW} \mathrm{TiO}{ }_{2}$ NPs encountered serious damage. Therefore, $\mathrm{TiO}_{2} \mathrm{NPs}$ are potentially dangerous for males when added to food products during the subacute period.

\section{Acknowledgements}

The present study received financial support from the National Natural Science Foundation of China (81560536), the Open Program of the Shanghai Key Laboratory of Atmospheric Particle Pollution Prevention (FDLAP14003), and the Science and Technology Research Program of Shihezi University (RCZX201331).

\section{References}

1. RIU J., MAROTO A., RIU F.X. Nanosensors in environmental analysis. Talanta, 69 (2), 288, 2006.

2. RUTH-MAGAYE J.Z., LINDA B., MIN D. Genotoxicity and carcinogenicity of cobalt-, nickel- and copper-based nanoparticles (Review). Exp. Ther. Med., 4 (4), 551, 2012.

3. SHI H., MAGAYE R., CASTRANOVA V., ZHAO J. Titanium dioxide nanoparticles: a review of current toxicological data. Part. Fibre. Toxicol., 10 (2), 1, 2013.

4. JIA F., SUN Z., YAN X.Y., ZHOU B.R., WANG J.D. Effect of pubertal nano- $\mathrm{TiO}_{2}$ exposure on testosterone synthesis and spermatogenesis in mice. Arch. Toxicol., 88 (3),781, 2013.

5. ESTERKIN C.R., NEGRO A.C., ALFANO O.M., CASSANO A.E. Air pollution remediation in a fixed bed photocatalytic reactor coated with $\mathrm{TiO}_{2}$. Aiche. J., 51 (51), 2298, 2005.

6. FUJISHIMAA., ZHANG X., TRYK D.A. TiO 2 photocatalysis and related surface phenomena. Surf. Sci. Rep., 63 (12), 515, 2005.

7. ZHEN S., QIAN Q., JIA G., ZHANG J., CHEN C., WEI Y. A panel study for cardiopulmonary effects produced by occupational exposure to inhalable titanium dioxide. J. 
Occup. Environ. Med., 54 (11),1389, 2012.

8. KAKINOK K., YAMANE K., TERAOKA R., OTSUKA M., MATSUDA Y. Effect of relative humidity on the photocatalytic activity of titanium dioxide and photostability of famotidine. J. Pharm. Sci., 93 (3), 582, 2004.

9. TAKEDA K., SUZUKI K.I., ISHIHARA A., Kubo-Irie M., FUJIMOTO R., TABATA M., OSHIO S., NIHEN Y., IHARA T., SUGAMATA M. Nanoparticles transferred from pregnant mice to their offspring can damage the genital and cranial nerve systems. J. Health Sci., 55 (1), 95, 2009.

10. WANG J., ZHOU G., CHEN C., YU H., WANG T., MA Y., JIA G., GAO Y., LI B., SUN J., LI Y., JIAO F., ZHAO Y., CHAI Z. Acute toxicity and biodistribution of different sized titanium dioxide particles in mice after oral administration. Toxicol. Lett., 168 (2), 176, 2007.

11. SONG B., LIU J., FENG X., WEI L., SHAO L. A review on potential neurotoxicity of titanium dioxide nanoparticles. Nanoscale Res. Lett., 10 (1), 1, 2015.

12. GERAETS L., OOMEN A.G., KRYSTEK P., JACOBSEN N.R., WALLIN H., LAURENTIE M., VERHAREN H.W., BRANDON E.F.A., DE JONG W.H. Tissue distribution and elimination after oral and intravenous administration of different titanium dioxide nanoparticles in rats. Part. Fibre. Toxicol., 11 (1), 30, 2014.

13. GAO G., ZE Y., ZHAO X., SANG X., ZHENG L., ZE X., GUI S., SHENG L., SUN Q., HONG J., YU X., WANG L., HONG F., ZHANG X. Titanium dioxide nanoparticleinduced testicular damage, spermatogenesis suppression, and gene expression alterations in male mice. J. Hazard Mater., 258-259 (16),133, 2013.

14. KOMATSU T., TABATA M., KUBO-IRIE M., SHIMIZU T., SUZUKI K.I., NIHEI Y., TAKEDA K. The effects of nanoparticles on mouse testis Leydig cells in vitro. Toxicol. in vitro, 22 (8), 1825, 2008.

15. MEENA R., KAJAL K., PAULRAJ R. Cytotoxic and genotoxic effects of titanium dioxide nanoparticles in testicular cells of male wistar rat. Appl. Biochem. Biotechnol., 175 (2), 825, 2015.

16. SONG G.L., GAO Y., WU H., HOU W.H., ZHANG C.Y., MA H.Q. Physiological effect of anatase $\mathrm{TiO}_{2}$ nanoparticles on lemina minor, Environ. Toxicol. Chem., 31 (9), 2147, 2012.

17. NAHAS S., HONDT H.A., ABDOU H.A. Chromosome aberrations in spermatogonia and sperm abnormalities in curacron-treated mice. Mutat. Res., 222 (4),409, 1989.
18. OKAMIJIMAK A.I., KAMIJIMA M., SHIBATA E., OHTANI K., TAKAGI K., UEYAMA J., WATANABE Y., OMURA M., WANG H.L., ICHIHARA G., KONDO T., NAKAJIMA T. A comprehensive evaluation of the testicular toxicity of dichlorvos in wistar rats. Toxicology, 213 (1-2), 129, 2005.

19. YAN J., AGRESTI M., BRUCE T., YAN Y., GRANLUND A., MATLOUB H. Effects of cellularphone emissions on sperm motility in rats, Fertil. Steril., 88 (4), 957, 2007.

20. BANCROFT D., STEVENS A., TURMER R. Theory and practice of histological technique, 4th ed. Churchill Living Stone, Edinburgh, 36-42, 1996.

21. MEKHAMER W.K. The colloidal stability of raw bentonite deformed mechanically by ultrasound. J. Saudi Chem. Soc., 14 (3), 301, 2010.

22. ANDERSSON P.O., LEJON C., EKSTRANDHAMMARSTROM B., AKFUR C., AHLINDER L., BUCHT A. Osterlund L. Polymorph- and Size-Dependent Uptake and Toxicity of $\mathrm{TiO}_{2}$ Nanoparticles in Living Lung Epithelial Cells. Small, 7 (4), 514, 2011.

23. WANG C., LI Y. Interaction and nanotoxic effect of $\mathrm{TiO}_{2}$ nanoparticle on fibrinogen by multi-spectroscopic method. Sci. Total Environ., 429 (429), 156, 2012.

24. ORAZIZADEH M., KHORSANDI L., ABSALAN F., HASHEMITABAR M., DANESHI E. Effect of betacarotene on titanium oxide nanoparticles-induced testicular toxicity in mice. J. Assist. Reprod. Genet., 31 (5), 1, 2014.

25. PEJIC ${ }^{\prime}$ S. Antioxidant enzymes and lipid peroxidation in endometrium of patients with polyps, myoma, hyperplasia and adenocarcinoma. Reprod. Biol. Endocrinol., 7 (1), 1, 2009.

26. JALALI-E-EMAM S.M.S., ALIZADEH B., ZAEFIZADEH M., ZAKARYA R.A., KHAYATNEZHAD M. Superoxide dismutase (SOD) activity in $\mathrm{NaCl}$ stress in salt-sensitive and salt-tolerance genotypes of Colza (Brassica napus L.). Middle East J. Sci. Res., 7 (1), 7, 2011.

27. WANG H.F., ZHONG X.H., SHI W.Y., GUO B. Study of malondialdehyde (MDA) content, superoxide dismutase (SOD) and glutathione peroxidase (GSHPx) activities in chickens infected with avian infectious bronchitis virus. Afr. J. Biotechnol., 10 (45), 9213, 2011. 